\title{
Voedingpraktyke en behoeftes van hulpbron-arm gemeenskappe deur die oë van laerskoolonderwysers
}

\author{
Authors: \\ Ronel Ferreira \\ William J. Fraser ${ }^{1}$ \\ Karien Botha ${ }^{1}$ \\ Elzaan Cook \\ Peet J. du Toit \\ Gerda Gericke
}

\section{Affiliations:}

${ }^{1}$ Institute for Food, Nutrition and Well-being, University of Pretoria, South Africa

\section{Correspondence to:}

Ronel Ferreira

Email:

ronel.ferreira@up.ac.za

\section{Postal address:}

2-57 Aldoel building,

University of Pretoria,

Pretoria 0002, South Africa

Dates:

Received: 26 Sept. 2013

Accepted: 28 Oct. 2013

Published: 09 Dec. 2013

How to cite this article: Ferreira, R., Fraser, W.J., Botha, K., Cook, E., Du Toit, P.J., Gericke, G. 2013, 'Voedingpraktyke en behoeftes van hulpbron-arm gemeenskappe deur die oë van laerskoolonderwysers', Suid-Afrikaanse Tydskrif vir Natuurwetenskap en Tegnologie 32(1), Art. \#779, 8 pages. http://dx.doi. org/10.4102/satnt.v32i1.779

\section{Note:}

This article forms part of a more comprehensive institutional research project, namely: 'Schools as sites for social change: Facilitating adjusted behaviour in resource-constrained communities by empowering children', funded by the Institute for Food, Nutrition and Well-being, University of Pretoria.

Read online:
In hierdie artikel bespreek ons die persepsies van onderwysers $(n=45)$ wat betref die voedingpraktyke van 'n steekproef laerskoolleerders en hul gesinne in 'n hulpbron-arm gemeenskap. Ons fokus spesifiek op die behoeftes, praktyke en verwagtings ten opsigte van die gebruik van voedsel, wat die produksie, keuse en voorbereiding van voedsel impliseer. Ons studie vorm die eerste deel van 'n groter institusionele navorsingprojek. Vir die doel van ons studie het ons deelnemende refleksie en aksie-gebaseerde werkwinkels gehou om data te genereer en tydens die interpretasie van bevindinge op interpretivisme staatgemaak. Hierdie studie beklemtoon die behoeftes van hulpbron-arm en werklose gemeenskapslede wat dikwels genoodsaak is om teen verlaagde pryse voedsel te koop waarvan die kwaliteit nie optimaal is nie. ' $n$ Verskraalde ontbyt, middagete of aandete waarvan die keuse algemeen beperk is tot swart tee, pap en een of twee snye ou brood, bevestig die manifestasies van armoede in hulpbron-arm gemeenskappe. Maaltye is dikwels beperk tot groot hoeveelhede koolhidrate, min groente, ingelegde vis, pap met inkomazi en marog. Hoenderpote en afval vul soms die spyskaart aan. Onderwysers beklemtoon die feit dat gemeenskapslede tipies op skenkings van werkgewers, kerke en kruidenierswinkels staatmaak om hul voedselbegroting aan te vul. Onderwysers fokus verder op die behoeftes aan opleiding vir gemeenskapslede. $\mathrm{Na}$ hulle mening moet gemeenskappe ingelig word oor voedselproduksie, groentetuine, die wyses waarop die kwaliteit van grond bepaal kan word, besproeiing en die toepassing van volhoubare wisselbou. Die artikel word afgesluit met uitvoerbare en leersame wenke vir die opleiding van landelike gemeenskappe. Op grond van dié navorsingsbevindinge word 'n intervensieprogram tans ontwikkel, met die doel om dit in die onderskeie deelnemende skole te implementeer ter bevordering van gesonde voedselverwante gedrag en welsyn.

Nutritional practices and needs of resource-constrained communities as seen through the eyes of primary school teachers. In this article we discuss the perceptions teachers $(n=45)$ have regarding the nutritional practices of a sample of primary school learners and their families in a resource-constrained community. We specifically focus on the needs, practices and expectations related to food consumption, which implies food production, food choice and food preparation. Our study forms the first part of a more comprehensive institutional research project. For the purpose of our study we utilised participatory reflection and action-based workshops with the participants in order to generate data, and employed interpretivism to interpret the findings. This study emphasises the need of resource-constrained and unemployed community members, who are often forced to purchase food as a reduced cost of which the quality is not optimal. An attenuated breakfast, lunch or dinner where choices are often limited to black tea, porridge and one or two slices of stale bread, confirms the manifestations of poverty in resource-constrained communities. Meals are often limited to large quantities of carbohydrates, few vegetables, canned fish, porridge with inkomazi and marog. Chicken feet and tripe may supplement the menu. Teachers emphasise the fact that community members typically rely on donations from employers, churches and grocery stores in order to supplement their food budget. Teachers furthermore focus on the needs of community members to be educated. In their view community members need to be informed in respect of food production, vegetable gardens, techniques of determining the quality of soil, irrigation and the application of sustainable crop rotation. The article concludes with achievable and informative ideas for educating rural communities. Based on these research findings an intervention programme is currently being developed, with the purpose of implementing the intervention in the various participating schools in support of healthy nutrition-related behaviour and well-being.

\section{Inleiding}

As deel van die Millennium Development Goals (MDGs) fokus die Verenigde Nasies tans, onder andere, op die bevegting van armoede, en die bereiking van gesondheids- en ontwikkelingsdoelwitte

Copyright: (c) 2013. The Authors. Licensee: AOSIS OpenJournals. This work is licensed under the Creative Commons Attribution License. 
wat verband hou met verhongering, kindermortaliteit, die gesondheid van moeders en instandhouding van die omgewing. Met spesifieke verwysing na verhongering, is die doelwit om die getal persone wat daardeur geraak word teen 2015 met 50\% te verminder (Fanzo \& Pronyk 2011; Statistics South Africa [STATSSA] 2010). Suid-Afrika, tans beskryf as 'n land waar die bewoners 'n gemiddelde inkomste het (STATSSA 2010), is deel van die groep lande wat nog nie daarin kon slaag om gesondheidsverwante doelwitte te bereik nie, onder andere weens uitdagings soos MIV of VIGS en nie-aansteeklike siektes (Stuckler, Basu \& McKee 2010). Ten einde die strewe na gesondheidsverwante doelwitte in Suid-Afrika te bestuur, stel STATSSA (2010) voor dat een moontlike strategie verband hou met die verbetering van kinders se omgewing in terme van watervoorsiening, voeding, sanitasie en gesonde voedsel.

Hulpbron-arm gemeenskappe in Suid-Afrika word gekenmerk deur armoede, werkloosheid en 'n gebrek aan werkgeleenthede, problematiese voedselverbouing en beperkte toegang tot waterbronne. Sodanige gemeenskappe moet dikwels swak gesondheids- en sanitêre omstandighede en praktyke, voedseltekort, asook ontoereikende diversifikasie en hanteringstrategieë met betrekking tot voedsel en dieet die hoof bied (Green, Botha \& Schönfelt 2010). Binne hierdie konteks hou voedselsekuriteit verband met 'the success of local livelihood strategies to guarantee access to sufficient food at the household or family level' [... die sukses van plaaslike stratregieë ten einde toegang te verleen tot voldoende voedsel op huishoudelike en gesinsvlak] (Devereux \& Maxwell, aangehaal deur Drimie \& Casale 2009:29).

Alhoewel patrone in wanvoeding oor die afgelope paar jaar skynbaar gestabiliseer het (United Nations 2012), word Suid-Afrikaners steeds deur uitdagings met betrekking tot voedselsekuriteit in die gesig gestaar. 'n Algemene problematiese verskynsel hou verband met die voedingslas wat meegebring word deur oorgewig moeders en ondergewig kinders (Kimani-Murage et al. 2010). Hierdie situasie noodsaak volgehoue navorsing oor voeding in die Suid-Afrikaanse konteks (Schönfeldt, Gibson \& Vermeulen 2010).

Ten einde voedseltekort te hanteer en die doelstellings te bereik wat in die Millennium Development Goals (United Nations 2012) uiteengesit is, is daar ' $n$ behoefte aan SuidAfrikaanse navorsing en intervensies met betrekking tot voedsel en voeding. Skoolgebaseerde studies in die vorm van intervensies impliseer die moontlikheid om kinders se gesondheid en ontwikkeling te bevorder, veral in ontwikkelende lande (Cortina et al. 2012). Aangesien leerders die grootste gedeelte van hul dag by die skool deurbring, en in die lig van die wêreldwye toename in laerskooltoelatings, bied die laerskool 'n ideale en kritiek belangrike konteks vir effektiewe intervensie, met spesifieke verwysing na gesondheid (Forneris et al. 2010; Naidoo \& Coopoo 2012).

\section{Moontlike waarde van skoolgebaseerde studies en intervensies}

Navorsing bevestig die moontlike waarde van skoolgebaseerde intervensies wat fokus op voedselinname, voeding en algemene gesondheid. Studies deur Gortmaker et al. (1999), en deur Prelip et al. (2011), het byvoorbeeld betekenisvolle veranderinge in onderwysers se algemene gesondheid tot gevolg gehad, asook in leerdergedrag wat betref voedselinname en gesonde voedingsverwante gedragspatrone. Hierbenewens bevestig 'n internasionale studie deur Steyn et al. (2009) die waarde van skoolgebaseerde voedingsverwante intervensies vir verandering wat betref kennis, vaardighede en gedrag met betrekking tot gesondheid.

Alhoewel van beperkte omvang, sluit die uitkomste van Suid-Afrikaanse skoolgebaseerde studies (Naidoo \& Coopoo 2012; Draper et al. 2010) 'n toename in fisieke aktiwiteit en die selfwerksaamheid van leerders in, asook beter kennis, persepsies en houdings wat gesondheid betref. Suksesvolle, skoolgebaseerde, voedingsverwante intervensies hou gewoonlik verband met alle vlakke van die kurrikulum, fisieke aktiwiteit en voedselvoorsiening, en sluit dikwels ook die gesin of 'n ouer as komponent in (Steyn et al. 2009).

Wanneer onderwysers binne die Suid-Afrikaanse konteks by skoolgebaseerde intervensiestudies betrek word, kry hulle die geleentheid om hul gemeenskaps-, burgerlike en pastorale rol uit te leef. Hierdie spesifieke rol vorm deel van die sewe kernrolle van die onderwyser, soos bepaal deur die eertydse Departement van Onderwys (Department of Education and Training 2010). Die oorblywende rolle van die onderwyser is dié van leerarea- of fasespesialis; fasiliteerder van leer; interpreteerder en ontwerper van leerprogramme en leermateriaal; leier, administrateur en bestuurder; geleerde, navorser en lewenslange leerder; asook assesseerder. Volgens die voormalige Departement van Onderwys (Department of Education and Training 2010:52) behoort 'n onderwyser, wat die gemeenskaps-, burgerlike en pastorale rol uitleef, 'ondersteunende verhoudings met ouers en ander sleutelpersone in organisasies gebaseer op kritiese begrip van gemeenskap- en omgewingontwikkelingaangeleenthede te bevorder'. Vir die doel van ons studie aanvaar ons dat onderwysers oor tersaaklike kennis van gemeenskapaangeleenthede beskik wat spesifiek na praktyke in voedselgebruik verwys.

\section{Konteks en doel van die studie}

Die studie waaroor ons rapporteer, vorm deel van 'n groter institusionele navorsingsprojek. Die meer omvattende projek fokus op die potensiaal van skole as terrein vir maatskaplike verandering wat betref voedselverwante gedragspatrone in hulpbron-arm gemeenskappe. Die projek het naamlik ten doel om die voedingsbehoeftes in hulpbronarm gemeenskappe te bestuur in 'n poging om die huidige gaping in voedingnavorsing in Suid-Afrika te takel. Die studie waaroor ons hier rapporteer, vorm deel van die eerste fase van die oorkoepelende projek. Teen die agtergrond 
van hierdie studie waaroor ons rapporteer, word ' $n$ plan vir intervensie tans ontwikkel om algemene gesondheid te verbeter, waardeur onderwysers in geselekteerde skole in hulpbron-arm gemeenskappe bemagtig sal word om verrykte inhoud aan kinders oor te dra, as deel van bestaande klaskameraktiwiteite. Die uiteindelike doel van die breë navorsingprojek is om te bepaal tot watter mate voedselen voedingsverwante gedragverandering gefasiliteer kan word deur middel van 'n skoolgebaseerde intervensie wat verhongering, wanvoeding en armoedverwante uitdagings bestuur en 'n gesonde leefwyse bevorder.

In hierdie artikel rapporteer ons derhalwe die basislyndata wat verband hou met deelnemende onderwysers se persepsies aangaande die praktyke van voedselverbruik van 'n steekproef laerskoolleerders en hul gesinne in 'n hulpbron-arm gemeenskap. Ons fokus spesifiek op die behoeftes, praktyke en verwagtinge met betrekking tot voedselverbruik, wat die produksie, keuse en voorbereiding van voedsel impliseer. Ons ondersoek sentreer sodoende om die voeding- en dieetverwante behoeftes van 'n hulpbronarm gemeenskap soos waargeneem deur onderwysers in drie skole. Meer spesifiek het die kennis, houdings, persepsies, waardes en voedingsverwante gedragpatrone van gesinne die fokus gevorm van die deelnemende onderwysers se waarnemings.

\section{Navorsingsontwerp}

In hierdie afdeling beskryf ons die metodologie van ons studie.

\section{Paradigmatiese keuses}

As rigtinggewende teoretiese raamwerk steun ons op die Food Decision-Making Framework (FDF). Hierdie raamwerk 'expands upon the notion of individual behavior change to consider behavior change within the context of families and communities' $[\ldots$ bou voort op die idee van individuele gedragsverandering ten einde gedragsverandering binne die konteks van die gesin en gemeenskap te oorweeg] (Gillespie \& Smith 2008:329). As sodanig is die raamwerk, onder andere, geskoei op die verweefde sisteme van individue se omgewings, soos ook voorgehou in Bronfenbrenner se Ekosistemiese Model (Tudge et al. 2009). Binne die konteks van ons studie erken die Food Decision-Making Framework die onderlinge verband tussen individue en gesinne se besluitneming oor voedsel binne ' $n$ voedselomgewing aan die een kant, en gesondheid en welsyn as uitkomste aan die ander kant (Gillespie \& Smith 2008). Hierdie argument bied 'n verklaring vir die invloed wat individue se omgewing op hul besluitneming oor voedsel het, asook vir sodanige omgekeerde invloed.

As metateorie het ons op interpretivisme (Taylor \& Medina 2013) staatgemaak en op persepsies en gedagtes van onderwysers en die aanbieding van hul standpunte en ervarings gefokus. Metodologies het ons 'n kwalitatiewe studie onderneem (Silverman 2010) en 'n aksienavorsingontwerp gevolg (Tomal 2010). Ons het meer spesifiek gebruik gemaak van Deelnemende Refleksie en Aksie (DRA) (Chambers 2008), en saam met onderwysers gewerk in ' $n$ poging om die afstand tussen teorie en praktyk te oorbrug (Brighton \& Moon 2007). Die wyse waarop ons gekose navorsingontwerp ooreenstem met die teoretiese raamwerk van die studie onderskryf 'n sistemiese benadering (Brighton \& Moon 2007).

\section{Deelnemende skole en onderwysers}

In gesprek met die Departement van Basiese Onderwys het ons drie laerskole in die Bronkhorstspruitdistrik geïdentifiseer as geskik vir ons studie. Vanweë die feit dat hierdie studie deel van 'n groter projek vorm, het ons van gerieflikheidsteekproefneming gebruik gemaak om die drie skole te identifiseer (Brighton \& Moon 2007). Hierbenewens het ons doelgerigte steekproefneming ingespan om die deelnemende onderwyser te selekteer (Maree \& Pietersen 2007). Seleksiekriteria het verband gehou met intermediêrefaseonderwysers, laerskole in die Bronkhorstspruitdistrik, bedrewenheid in Engels en ' $n$ bereidwilligheid om deel te neem. Onderskeidelik 12, 18 en $15(n=45)$ onderwysers uit drie skole in die gebied het aan die studie deelgeneem.

\section{Data-insameling, -dokumentering en -analise}

Ons het data tydens DRA-gebaseerde werkswinkels ingesamel (Chambers 2008). Ooreenstemmend met DRA-beginsels was ons aanname dat die deelnemers oor inligting beskik en deur hulle gedeel sal word (onderwysers in die onderhawige geval). Gedurende Februarie 2013 het ons individuele werkswinkels by elk van die drie deelnemende skole gefasiliteer waartydens onderwysers in groepe van vier of vyf deelnemers gewerk het. Die werkswinkels het twee ure elk geduur. Ons het vier vrae ${ }^{1}$ aan die groepe onderwysers gestel wat die vrae dan in klein groepe bespreek en daarna hul voorstelle op 'n plakkaat aan die groter groep aangebied het. Vrae is telkens aan die hand van 'n prent bekend gestel, om aanvanklike gedagtes rondom die aspek wat bespreek is te fasiliteer.

Tydens groepbesprekings het ons as navorsers aan die besprekings deelgeneem. Eie aan aksienavorsing was ons deurgaans sensitief vir verdere behoeftes wat moontlik deur die deelnemers aangedui sou word tydens gesprekvoering, of alternatiewe vrae wat beantwoord moes word. Na voltooiing van die data-analise is bevestiging deur deelnemers tydens opvolgveldbesoeke in Augustus 2013 en September 2013 gedoen. In ooreenstemming met die DRA-gedrewe werkswinkels het ons van veldnotas, waarneming, oudioopnames en visuele plakkate gebruik gemaak om gesproke en geskrewe inligting vas te lê (Nieuwenhuis 2007; Tessier 2012). Reflektiewe skryfwerk in die vorm van 'n reflektiewe joernaal het die navorsers se refleksie vergemaklik (Ortlipp 2008; Spiegel \& Foulk 2006).

Data-insameling is opgevolg deur induktiewe, tematiese data-analise (Patton 2002) ten einde herhalende temas en subtemas te identifiseer. Ons navorsing is deurgaans deur

1.Die vrae was soos volg: (1) Wat eet ouers en kinders in hierdie gemeenskap gewoonlik elke dag? (2) Waar kry hulle hul kos vandaan? (3) Watter riglyne of kennis of vaardighede het ouers nodig ten opsigte van voedselproduksie, voedselkeuse en voedselhet ouers nodig ten opsigte van voedselproduksie, voedselkeuse en voedsel-
voorbereiding? (4) Watter soort inligting dink jy kan ingesluit word in die verskillende graad 4-6-leerareas met die doel om kennis aan gemeenskappe oor te dra? 
etiese oorwegings gerig, wat deur prosesmatige, situasionele, relasionele en bestaande praktyke gestuur is (Tracy 2010).

\section{Bevindinge}

Drie hooftemas is tydens tematiese analise geïdentifiseer, te wete eetpatrone; tipiese voedselbronne; en behoeftes van die gemeenskap aan kennis en vaardighede.

\section{Tema 1: Eetpatrone}

Tydens die DRA-werkswinkels, het die deelnemende onderwysers bevestig dat die gemeenskap as hulpbron-arm beskryf kan word en dat talle gemeenskapslede werkloos is:

'Dit is voorwaar ' $n$ baie arm gemeenskap ... omdat baie ouers in die gebied werkloos is.' (Skool A, deelnemende onderwyser 10)

'Die meeste ouers werk nie, dit is slegs 'n klein persentasie ... die meerderheid ouers wat wel werk, werk as huishulpe en dit is bekend hoe min hulle verdien ... hulle is nie in staat om duur vars produkte te koop nie ... die meerderheid koop goedkoop kos waarvan die prys verminder is; R5-kopies met ' $n$ rooi plakker is wat hulle kan bekostig.' (Skool B, deelnemende onderwyser 14)

Ondanks die armoede en hoë werkloosheidsyfer was verskeie onderwysers steeds hoopvol:

'Ek kom ook uit 'n arm gesin, maar was bevoorreg om die geleentheid te kry om my studies voort te sit. Gevolglik is ek vandag in staat om myself en my gesin te voed.' (Skool A, deelnemende onderwyser 1)

Sub-tema 1.1 - Ontbyt: Tydens die DRA-gebaseerde werkswinkels het deelnemers aangedui dat die ontbyt van meeste van die ouers en kinders uit pap, brood en tee bestaan:

'Hulle drink tee sonder melk ... hulle eet gaar pap of drie dae oue brood.' (Skool A, deelnemende onderwyser 1)

'So $5 \%$ leerders drink tee saam met stywe pap en $60 \%$ leerders eet tee en brood ... By die skool word voedsame pap aan die leerders gegee.' (Skool B, deelnemende onderwyser 7)

'Ons leerders eet slap pap by die skool en die ouers eet die vorige dag se stywe pap en drink soms tee sonder melk daarmee saam.' (Skool C, deelnemende onderwyser 16)

'Party eet pap en drink tee; ander eet net brood sonder botter saam met tee.' (Skool C, deelnemende onderwyser 1)

Sub-tema 1.2 - Middagete: Deelnemers het aangedui dat gemeenskapslede se middagete gewoonlik uit koolhidrate, groente en soms ingelegde vis bestaan indien hulle wel middagete nuttig:

'Die ouers kry brood en atjar, 'n vasgestelde kwota, soms genoem spatlho ... dit is brood met atjar, koue vleis ensovoorts ... of party eet pap met inkomazi en marog.' (Skool A, deelnemende onderwyser 4)

'Ouers en leerders eet ' $n$ uitgeholde brood ... en $20 \%$ van die gemeenskap eet nie middagete nie omdat daar nie kos of geld vir kos is nie.' (Skool C, deelnemende onderwyser 8)

'Sommige gemeenskapslede eet enigiets van die vullishoop af.' (Skool C, deelnemende onderwyser 15)

Met spesifieke verwysing na die kinders in die gemeenskap, het onderwysers soos volg gerapporteer:
'By die skool gee ons hulle soms brood, stampmielies en boontjies.' (Skool B, deelnemende onderwyser 13)

'Vir middagete eet die meerderheid leerders brood en atjar, pap en ingelegde vis, bene en kopkool by die skool.' (Skool B, deelnemende onderwyser 11)

'Gewoonlik eet hulle slegs brood en tee, maar gelukkig vir die kinders by die skool bied ons hulle pap en kopkool op sommige dae aan; soms kry hulle rys met vis en op ander dae stampmielies en groente. Een keer per week kry hulle 'n appel of 'n piesang as middagete.' (Skool C, deelnemende onderwyser 10)

Sub-tema 1.3 - Aandete: Tydens die DRA-gebaseerde werkswinkels het die deelnemers aangedui dat gemeenskapslede gewoonlik koolhidrate saam met groente en soms hoendervleis tydens aandete nuttig:

'Tydens aandete het ons ouers gewoonlik vir ons spinasie gekook; in townshiptaal noem ons dit umrogo en pap, soms saam met blikkiesvis gemeng met tamatie en uie en dan het ons vir die nag geëet.' (Skool A, deelnemende onderwyser 7)

'Die meerderheid eet pap, vleis, party met hoendervleis alhoewel baie min toegang daartoe het.' (Skool B, deelnemende onderwyser 12)

'Die meerderheid eet pap en melk, kopkool, boontjiesop, hoenderkoppe, hoenderpote, nekke en die hoendermagie.' (Skool C, deelnemende onderwyser 3)

Sommige gemeenskaplede (en kinders) het stellig nie die middele om ' $n$ behoorlike aandete te nuttig nie:

'Die meerderheid eet pap en marog ... slegs 2\% kry 'n behoorlike aandete, terwyl ander kos van die vullishoop kry; sommige kry kos van die huise waar hulle ouers as huishulpe werk.' (Skool C, deelnemende onderwyser 13)

\section{Tema 2: Tipiese voedselbronne}

In antwoord op die vraag waar gemeenskaplede hul voedsel vandaan kry, het deelnemers 'n verskeidenheid bronne aangedui.

Sub-tema 2.1 - Skenkings deur organisasies: Deelnemende onderwysers het aangedui dat sommige gemeenskaplede op donasies staatmaak om in hul daaglikse voedselbehoeftes te voorsien. Werkgewers, kerke en kruidenierwinkels is as moontlike skenkers genoem:

'Ons het uitgevind dat ons leerders ná skool na Kids Care gaan waar kos elke middag uitgedeel word.' (Skool A, deelnemende onderwyser 9)

'In ons skool het ons in vennootskap getree met 'n kerk in Pretoria waarvolgens ons veral weeskinders identifiseer ... ons voorsien hulle van kospakkies en kruideniersware, en ons kry ook donasies van gemeenskapsgebaseerde instansies.' (Skool C, deelnemende onderwyser 7)

'Pick 'n Pay en Spar het kospakkies geskenk ... soms is daar gemeenskapsleiers wat daarheen gaan en die kospakkies vir die mense insamel.' (Skool A, deelnemende onderwyser 1)

'Hulle kry ook oorskietkos van hulle werknemers; veral huishulpe.' (Skool A, deelnemende onderwyser-12)

'... en ook vanaf sosiale funksies, begrafnisse en troues ... sommige mense het moontlik nie opgedaag nie; dan nooi mens die gemeenskap om 'n gratis maaltyd te kom geniet.' (Skool B, deelnemende onderwyser 2) 
Sub-tema 2.2 - Plaaslike winkels en handelaars: Deelnemers het vervolgens aangedui dat gemeenskaplede soms hul voedsel van plaaslike en nabygeleë winkels verkry wat kos teen redelike pryse aanbied:

'Ons het ' $\mathrm{n}$ supermark met die naam Cash and Carry. Die supermark hou bekostigbare voedsel vir die plaaslike mark aan. Dit beteken alles in die supermark is goedkoop.' (Skool A, deelnemende onderwyser 6)

'Op die plaaslike dorp koop ons van winkels soos Shoprite, Spar, Bronco Chicken Centre, Pick 'n Pay en Cash and Carry waar ' $n$ mens teen ' $n$ laer prys kan koop.' (Skool C, deelnemende onderwyser 15)

'Sommiges kry hulle kos van spazawinkels, sommige op die dorp maar dit is slegs vir die middelklas ... dié wat vervoer het, dié wat 'n taxi kan bekostig, dié wat verkies om grootmaataankope te doen.' (Skool B, deelnemende onderwyser 12)

Hierbenewens verkry sommige gemeenskaplede na oorlewering hul voedsel van plaaslike handelaars:

'Party koop op die straathoeke, dinge soos hoenderpote, hoendermagies, hoendernekke, ensovoorts.' (Skool B, deelnemende onderwyser 11)

'Ons het ook straatverkopers.' (Skool C, deelnemende onderwyser 9)

Sub-tema 2.3 - Stortingterreine: Derdens het die deelnemers aangedui dat sommige gemeenskaplede geen voedsel kan bekostig nie en derhalwe honger sal bly of kos van stortingterreine of in vullisdromme kry:

'Die meerderheid ouers in XXX kom van buite die landgrense ... Mosambiek en Zimbabwe ... hulle het nie toegang tot regeringsubsidies in Suid-Afrika nie ... die getalle vermeerder daagliks ... baie gaan slaap honger.' (Skool A, deelnemende onderwyser 3)

'Ander werkloses wag by die vullishope op die trokke vanaf die slagpale om bene op te tel ... hulle wag vir kos waarvan die vervaldatum verstreke is.' (Skool A, deelnemende onderwyser 10)

'Selfs op die vullishope het ouers afgebakende gebiede ... iemand kan nie sonder meer daarheen gaan en die gebied betree of infiltreer nie ... jy sal doodgemaak word.' (Skool B, deelnemende onderwyser 4)

'Sommige mense eet uit die vullisdromme en van die stortingterrein.' (Skool C, deelnemende onderwyser 5)

Sub-tema 2.4 - Gemeenskapsgebaseerde groentetuine: Gemeenskaplike groentetuine is as 'n belangrike wyse van bekamping van verhongering en armoede beklemtoon:

'Ons sien ouer persone wat groentetuine aangelê het vir die verbouing van spinasie, mielies, kopkool en ander groentesoorte.' (Skool A, deelnemende onderwyser 4)

'Ons het gevind dat die meeste mense in die gemeenskap hulle kos uit groentetuine kry.' (Skool C, deelnemende onderwyser 14)

\section{Tema 3: Gemeenskap se behoefte aan kennis en vaardighede}

Besprekings tydens die DRA-gebaseerde werkwinkels het daarop gedui dat die gemeenskap 'n behoefte het aan kennis, riglyne en vaardighede oor voedselproduksie, voedselkeuse en voedselvoorbereiding. Een onderwyser het gesê:
'Ons gemeenskapslede het 'n behoefte aan werkwinkels en opleiding.' (Skool B, deelnemende onderwyser 11)

Onderwysers het oënskynlik verantwoordelik en kundig genoeg gevoel om hulp aan te bied:

'Ons as onderwysers behoort leiding te neem.' (Skool B, deelnemende onderwyser 12)

'Ons kan hulle inlig omtrent gesonde voedselkeuses en hulle van riglyne oor voeding voorsien.' (Skool A, deelnemende onderwyser 3)

Sub-tema 3.1 - Voedselproduksie: Die onderwysers was van mening dat gemeenskapslede spesifieke kennis en vaardighede moes bekom ten einde hul eie voedsel te kan produseer:

'Daar is ' $\mathrm{n}$ behoefte aan opleiding hoe om voedsel te produseer, want dit wil voorkom asof die gemeenskap oor min inligting of min kennis beskik.' (Skool A, deelnemende onderwyser 4)

Deelnemers het aangedui dat die gemeenskap 'n behoefte aan spesifiek leiding het wat betref onafhanklike groenteproduksie:

'... hoe om jou eie groentetuin te maak en vrugtebome te versorg ...' (Skool B, deelnemende onderwyser 8)

'Die gemeenskap moet aangemoedig word om groentetuine te maak in die klein ruimtes in hul agterplase.' (Skool C, deelnemende onderwyser 13)

Deelnemers het beklemtoon dat die gemeenskap 'n behoefte het aan hulp en bronne ten einde selfvoorsienende produsente te word:

'Hulle moet "starter packs" ontvang; individue moet byvoorbeeld voorsien word van saad en tuingereedskap.' (Skool B, deelnemende onderwyser 6)

'... daar is 'n behoefte aan gereedskap soos tuinvurke, grawe en ploeë.' (Skool A, deelnemende onderwyser 11)

Deelnemende onderwysers het die noodsaaklikheid besef vir die gemeenskap om opgevoed te word ten einde onafhanklikheid te bereik:

'Daar is ' $n$ behoefte aan ' $n$ professionele persoon om hulle te leer hoe om hul eie tuingereedskap te maak en te gebruik. Hulle moet ook aangemoedig word om 'n eie groentetuin in hul agterplase aan te lê.' (Skool C, deelnemende onderwyser 2)

Hierbenewens was sommige onderwysers van mening dat:

'... die gemeenskap moet leer hoe om gebruik te maak van wat ook al tot hul beskikking is en dit nie vermors nie.' (Skool B, deelnemende onderwyser 4)

'Ons moet elke bron tot ons beskikking gebruik.' (Skool B, deelnemende onderwyser 7)

Deelnemers het verskeie aspekte met betrekking tot plante, grond en water geïdentifiseer waar daar na hul mening, 'n behoefte aan inligting in die gemeenskap is. Hulle het byvoorbeeld aangedui dat die gemeenskap inligting oor die verbouing van plante moet kry:

'... 'n omgewing wat hom leen tot optimale groei, en gemeenskapslede het ' $n$ behoefte aan spesifieke inligting oor hulle eie plante.' (Skool A, deelnemende onderwyser 10)

Asook oor grondsoorte: 
'Hulle moet grondsoorte kan identifiseer.' (Skool B, deelnemende onderwyser 10)

Wisselbou:

'Hulle moet ook onderrig word oor gewasse wat in verskillende seisoene verbou word.' (Skool A, deelnemende onderwyser 6),

en bemesting:

'... bemesting, besproeiing en die gebruik van omgewings-

vriendelike insekdoders ...' (Skool B, deelnemende onderwyser 9)

Met verwysing na die belangrikheid van water het deelnemers voorstelle gemaak wat betref die probleem dat alle gemeenskapslede nie oor genoegsame waterbronne beskik nie:

'Ons besef ook dat water baie belangrik is en het genoem dat jojo-tenks nodig is ... omdat munisipale water duur is en daarom behoort mense aangemoedig te word om tenks tuis te gebruik vir opvang van reënwater.' (Skool A, deelnemende onderwyser 11)

Bo en behalwe hierdie aspekte was die deelnemers van mening dat die gemeenskap ' $n$ behoefte het aan leiding, kennis en vaardighede betreffende veeboerdery:

'Hulle het 'n behoefte aan vaardighede en inligting oor hoenderboerdery, varkboerdery en beesboerdery.' (Skool B, deelnemende onderwyser 1)

'Hulle moet meer van lewende hawe weet, byvoorbeeld die gebruik van 'n broeikas.' (Skool A, deelnemende onderwyser 2)

'Hulle moet boerderyvaardighede aanleer.' (Skool B, deelnemende onderwyser 12)

Benewens die behoefte aan sulke spesifieke boerderyvaardighede het deelnemers voorgestel dat die gemeenskap moontlik kan baat by kennis oor hoe om grond te bekom:

'Inligting behoort aan hulle verskaf te word hoe om grond vir boerdery te bekom, want dit beteken niks as hulle geld het, maar nie weet waar om te gaan boer nie.' (Skool C, deelnemende onderwyser 3)

Sub-tema 3.2 - Voedselkeuse: Deelnemende onderwysers was van mening dat die gemeenskap 'n behoefte aan opleidingsessies oor ' $n$ gebalanseerde dieet het:

'Gemeenskaplede het ' $n$ behoefte aan werkwinkels en opleiding oor gesonde voedsel en 'n gebalanseerde dieet ... ons dink dit is baie belangrik vir ons gemeenskap.' (Skool B, deelnemende onderwyser 15)

"n Gebalanseerde dieet is baie belangrik. Die gemeenskap eet slegs pap en vleis, melk en pap, kopkool en pap; daarom sien ' $\mathrm{n}$ mens dat hulle ondervoed is.' (Skool A, deelnemende onderwyser 10)

In dié verband het die deelnemers beklemtoon dat gemeenskapslede:

'... voedsel vir 'n gebalanseerde dieet moet koop in plaas van gemorskos ... vetterige kossoorte moet ook vermy word.' (Skool $\mathrm{B}$, deelnemende onderwyser 7)

Deelnemers het pertinent aanbeveel dat die gemeenskap van die voedselpiramide geleer moet word en dat hulle ingelig moet word dat:

'... hulle wit vleis bo rooi vleis moet kies, bruinsuiker bo witsuiker, rooibostee bo koffie en hulle moet water drink in plaas van gaskoeldrank, en melk in plaas van sap.' (Skool C, deelnemende onderwyser 15)
Sommige deelnemers het veldtogte voorgestel om 'n gesonde dieet te bevorder:

'Individue moet opgevoed word om gesonde voedsel te eet ... ons moet redes verskaf waarom hulle nie gemorskos moet eet nie; daar moet ook ' $n$ verduideliking wees waarom hulle by ' $n$ gesonde gebalanseerde dieet moet hou en nie gemorskos moet eet nie.' (Skool B, deelnemende onderwyser 14)

'Mense moet geleer word om gesonde kos te koop en voor te berei wanneer hulle hul regeringtoelaag ontvang' (Skool B, deelnemende onderwyser 9).

Hierbenewens het deelnemers vermeld dat gemeenskapslede ' $n$ behoefte het aan riglyne oor vervaldatums:

'Ons moet hulle leer om vervaldatums te kontroleer.' (Skool C, deelnemende onderwyser 12)

Ten slotte was die onderwysers gemotiveerd om die gemeenskap in te lig oor die belangrikheid van water:

'Dit is baie belangrik om water te drink; as jy nie water drink nie, sal jy voel iets is nie reg in jou liggaam nie ... jy het water regtig nodig.' (Skool B, deelnemende onderwyser 15)

'Hulle moet aangemoedig word om baie water in plaas van sap te drink.' (Skool C, deelnemende onderwyser 12)

Sub-tema 3.3 - Voedselvoorbereiding: Tydens die werkwinkels het deelnemende onderwysers aangedui dat gemeenskapslede riglyne en spesifieke inligting oor voedselvoorbereiding moet kry:

'Hulle het ' $n$ behoefte aan iemand om hulle te leer hoe om voedsel op 'n gesonde wyse voor te berei.' (Skool C, deelnemende onderwyser 13)

'Hulle kan ook baat by werkwinkels en opleiding oor voedselhigiëne en hoe om voedsel te hanteer.' (Skool B, deelnemende onderwyser 11)

Deelnemers het aangedui dat die gemeenskap ' $n$ behoefte het aan vaardighede om voedsel te preserveer, asook inligting oor die korrekte gaarmaakmetodes:

'Hulle kort inligting oor gaarmaakmetodes en gaarmaaktye want hulle kook blindelings - hulle kook die kos te lank en hulle moet riglyne kry vir die preservering van voedsel sodat hulle nie so gereeld hoef kos te koop nie.' (Skool B, deelnemende onderwyser 7)

'Daar moet kookdemonstrasies gehou word en daarna sessies oor voedselpreservering vir diegene wat nie yskaste het nie. Individue moet aangemoedig word om voedsel te preserveer as hulle nie die nodige toestelle kan bekostig nie.' (Skool A, deelnemende onderwyser 11)

Deelnemende onderwysers het hulself as kundig en gemotiveerd genoeg beskou om gemeenskapslede te help om gesonder voedselvoorbereidingpraktyke te bemeester:

'Ons moet kosdemonstrasies hou.' (Skool B, deelnemende onderwyser 9)

'Ons sal hulle inlig omtrent...' (Skool B, deelnemende onderwyser 5)

'Ons moet hulle aanmoedig om...' (Skool A, deelnemende onderwyser 1)

Onderwysers het die feit beklemtoon dat hulle, as onderwysers, gemeenskapslede selfversorgend wil maak en entrepreneurskap in die gemeenskap wil bevorder: 
'Ons wil hulle help om hulle eie werkgeleenthede te skep ... hulle kan 'n kookklub of spysenierklub stig wat kan geld maak omdat ons hulle sal huur om by troues en gesellighede te spysenier.' (Skool B, deelnemende onderwyser 2)

\section{Bespreking}

In ons studie het onderwysers verskeie terreine geïdentifiseer waar gemeenskapslede ingelig en toegerus behoort te word om gesonde voedselpraktyke te bevorder. Onderwysers het hulself genoegsaam ingelig geag om 'n rol in hierdie proses te speel. Hulle was gemotiveerd om hul kennis en vaardighede ter bevordering van die welsyn van die gemeenskap aan te wend deur byvoorbeeld inligting oor die effektiewe keuse, voorbereiding en gebruik van voedsel by die huidige kurrikulum vir die intermediêre fase te integreer. Hierdie moontlikheid vorm die basis vir die skoolgebaseerde intervensie wat tans ontwikkel en in 2014 geïmplementeer sal word, as deel van die meer omvattende navorsingsprojek.

Skole en veral onderwysers is goed geposisioneer om 'n onderskragende rol in hulpbron-arm gemeenskappe te speel. Onderwysers vul 'n prominente rol in die blootstelling van leerders aan die doelstellings en uitkomste van nasionale skoolkurikula wat binne die groter raamwerk en tydbeperkings van 'n semesterprogram geskied. Alternatiewelik kan hul betrokkenheid by gemeenskapslede 'n addisionele kurrikulumopgaaf word waar kundigheid en vaardighede buite skoolure en buite die formele skoolbegroting gedeel kan word met die gemeenskap. Hulle beskik wel oor die nodige insig in en begrip vir die besondere uitdagings met betrekking tot die konteks van die skoolgemeenskap waarin hulle werk. Hierbenewens speel hulle 'n sleutelrol in die ontwikkeling en vorming van die toekomstige burgers van ons land.

In die Suid-Afrikaanse konteks, waar armoede, werkloosheid en teenspoed aan die orde van die dag is, is intervensie op voetsoolvlak noodsaaklik in 'n poging om kwesbare gemeenskappe op te hef. In die lig van die feit dat eksterne hulpbronne beperk is en dat party gemeenskappe dikwels nie toegang het tot sodanige hulpbronne nie, moet sodanige gemeenskappe self eienaarskap neem betreffende oplossings vir die uitdagings wat hulle in die gesig staar. Hulle moet tipies op die hulpbronne wat wel beskikbaar is in hul onmiddellike omgewing staatmaak om krisisse te oorkom. Onderwysers kan as een sodanige hulpbron beskou word. Om onderwysers egter as hulpbron aan te wend, vereis veelvoudige oorwegings wat die professie nie tans buite die formele skoolkurrikulum kan bekostig nie. Onderwysers is reeds ooreis deur verlengde skoolure, uitgebreide kurrikula, hoër toelatingsyfers, die steeds toenemende eise van unies, verminderde begrotings en onderwysertekorte. Talle skoolterreine het reeds hul kapasiteit vir die produksie van genoegsame groente vir die behoeftes van die skoolgemeenskappe oorskry en die begrotings van skole kan moeilik gerek word om die oorhoofse koste van sodanige verbeterings ook te dra. Alhoewel hierdie navorsingterrein eers tydens die opvolgfase van die groter navorsingprojek breedvoerig ondersoek sal word, dui die basislyninligting wat ons bekom het daarop dat voedselverwante inligting waarskynlik primêr in die vakke Lewensoriëntering, Natuurwetenskappe en Tegnologie ingesluit sal kan word.

Die onderwysers wat aan ons studie deelgeneem het, het spesifiek voorgestel dat inligting oor 'n gebalanseerde dieet, gesonde eetgewoontes, die voedselpiramide, inheemse voedsel en entrepreneurskap in Lewensoriëntering aan leerders oorgedra kan word. Hulle beskou inligting oor boerdery met lewende hawe (met spesiale klem op hoenderboerdery), die belangrikheid van water as 'n hulpbron, die waarde van plante vir menslike gebruik, die implementering van wisselbou en die identifisering van grondsoorte as geskik vir insluiting in die Natuurwetenskappe-kurrikulum. Wat die vak Tegnologie betref, het deelnemers voorgestel dat inligting oor voedselprosessering, en die rol en gebruik van toerusting moontlik ingesluit kan word by die bestaande kurrikulum. Hierbenewens kan ander skoolvakke bykomende inligting insluit ten einde die boodskap van gesonde voedselpraktyke kruiskurrikulêr aan graad 4-6 leerders oor te dra.

Die inligting waaroor onderwysers beskik, stel hulle in staat om leeraktiwiteite in konteks te plaas en om outentieke leergeleenthede vir leerders daar te stel. Leer wat in konteks plaasvind, met ander woorde waar leerders 'n direkte verband kan trek tussen die nuwe inhoud wat bemeester word en hul lewenswerklike omgewing, is betekenisvol en geneig om volhoubare gedragsverandering te fasiliteer. 'n Verdere implikasie is dat onderwysers op hierdie wyse bemagtig word om die bestaande skoolkurrikula te integreer met die behoeftes van die gemeenskap. Hierbenewens sal onderwysers bemagtig word om 'n bydrae te lewer tot kurrikuleringsaktiwiteite deur waarde tot die inhoud en prosesse van die onderskeie kurrikula toe te voeg.

\section{Slot}

Indien onderwysers daarin sou slaag om leerders ten opsigte van voeding en gesonde voedingverwante gedrag op te voed, bestaan die moontlikheid dat leerders op hul beurt die nuut verworwe kennis, vaardighede en voedselverwante gedrag na die gemeenskap sal oordra. In die lig van die geselekteerde teoretiese raamwerk (Food Decision-Making Framework) wat daarop neerkom dat gedragsveranderinge eers individueel moet geskied alvorens veranderinge in die konteks van gesinne en gemeenskappe kan plaasvind, bevestig die raamwerk die moontlikheid dat leerders wysiginge sal assimileer en akkommodeer. Wanneer dit plaasgevind het, sal leerders oor die nodige kennis en vaardighede beskik om gedragswysiging in die gemeenskap te fasiliteer. Dit kan moontlik tot die verligting van wanvoeding en verhongering bydra, veral in hulpbron-arm gemeenskappe. Talle van hierdie aannames is egter nog nie in die Suid-Afrikaanse konteks getoets nie, wat die vraag steeds laat of veral laerskoolleerders wel uiteindelik die wil, vaardighede en kapasiteit sal kan ontwikkel om tot voedselproduksie en die verligting van verhongering by te dra, al dan nie. Hierdie werkende aanname vereis voortgesette navorsing, ten einde uiteindelik volhoubare gedragsverandering in gemeenskappe te bevorder. 


\section{Erkenning Outeursbydrae}

Die deelnemende navorsers in hierdie projek was E.C. (Universiteit van Pretoria) verantwoordelik vir datainsameling, K.B. (Universiteit van Pretoria) vir datainsameling en -analise, R.F. (Universiteit van Pretoria) en W.J.F. (Universiteit van Pretoria) vir die interpretasie en skryf van finale artikel, en laastens was P.J.d.T. (Universiteit van Pretoria) en G.G. (Universiteit van Pretoria) verantwoordelik vir kritiese insette en redigering.

\section{Mededingende belange}

Die outeurs verklaar hiermee dat hulle geen finansiële of persoonlike verbintenis het met enige party wat hulle nadelig of voordelig kon beïnvloed het in die skryf van hierdie artikel nie.

\section{Literatuurverwysings}

Brighton, C.R. \& Moon, T.M., 2007, 'Action research step-by-step: A tool for educators to change their world', Gifted Child Today 30(2), 23-27.

Chambers, R., 2008, 'Revolutions in development inquiry', Earthscan, London.

Cortina, M.A., Kahn, K., Fazel, M., Hlungwani, T., Tollman, S., Bhana, A., ProthrowStith, D. \& Stein, A., 2012, 'School-based interventions can play a critical role in enhancing children's development and health in the developing world', Childcare, health and development 34(1), 1-3. http://dx.doi.org/10.1111/j.13652214.2007.00820.x, PMid:18171436

Department of Higher Education and Training, 2010, 'Draft Policy on Minimum Requirements for Teacher Education Qualifications selected from the HEQF', http://www.dhet.gov.za/LinkClick.aspx?fileticket=x/q3U3/0qSo

Draper, C.E., De Kock, L., Grimsrud, A.T., Rudolph, M., Nemutandani, S., Kolbe Alexander, T. \& Lambert, E.V., 2010, 'Evaluation of a school-based physical activity intervention in Alexandra Township', South African Journal of Sports Medicine 22(1), 12-19.

Drimie, S. \& Casale, M., 2009, 'Multiple stressors in Southern Africa: The link between HIV/AIDS, food insecurity, poverty and children's vulnerability now and in the future', AIDS Care 21(1), 28-33, http://dx.doi.org/10.1080/09540120902942931

Fanzo, J.C. \& Pronyk, P.M., 2011, 'A review of global progress toward the Millennium Development Goal 1 Hunger Target', Food and Nutrition Bulletin 32(2), 144-158. PMid:22164975

Farrokhi, F., 2012, 'Rethinking convenience sampling: Defining quality criteria', Theory and Practice in Language Studies 2(4), 784-792, http://dx.doi.org/10.4304/ tpls.2.4.784-792

Forneris, T., Fries, E., Meyer, A., Buzzard, M., Uguy, S., Ramakrishnan, R., Lewis, C \& Danish, S., 2010, 'Results of a rural school-based peer-led intervention for C \& Danish, S., 2010, Results of a rural school-based peer-led intervention for youth: Goals for health', Journal of School Health $80(2)$,
org/10.1111/j.1746-1561.2009.00466.x, PMid:20236403

Gillespie, A.H. \& Smith, L.E., 2008, 'Food Decision-Making Framework: Connecting sustainable food systems to health and well-being', Journal of Hunger and Environmental Nutrition 3(2/3), 328-346. http://dx.doi.org/10.1080/193202408 02244363

Gortmaker, S.L., Cheung, L.W.Y., Peterson, K.E., Chomitz, G., Cradle, J.H., Dart, H., Fox, M.K., Bullock, R.B., Sobol, A.M., Colditz, G., Field, A.E. \& Laird, N., 1999, 'Impact of a school-based interdisciplinary intervention on diet and physical activity among urban primary school children. Eat well and keep moving', Archives of Pedriatrics and Adolescent Medicine 153, 975-983. http://dx.doi.org/10.1001/ archpedi.153.9.975, PMid:10482216

Green, C., Botha, P. \& Schönfelt, H.C., 2010, 'Needs assessment in a rural community on a commercial farm in South Africa', Journal of Family Ecology and Consumer Sciences 32, 46-59. http://dx.doi.org/10.4314/jfecs.v32i1.52848

Kimani-Murage E.W., Kahn K., Pettifor J.M., Tollman S.M., Dunger D.B., GomezOlive X.F. \& Norris S.A., 2010, 'The prevalence of stunting, overweight and obesity, and metabolic disease risk in rural South African children' BMC Public Health 10, 158. http://dx.doi.org/10.1186/1471-2458-10-158, PMid:20338024, PMCid:PMC2853509

Maree, K. \& Pietersen, J., 2007, 'Sampling', in K. Maree (ed.), First steps in research, pp. 171-181, Van Schaik Publishers, Pretoria.

Naidoo, R. \& Coopoo, Y., 2012, 'The impact of a primary school physical activity intervention in KwaZulu-Natal, South Africa', African Journal for Physical, Health Education, Recreation and Dance 18(1), 75-85.

Nieuwenhuis, J., 2007, 'Qualitative research designs and data gathering techniques', in K. Maree (ed.), First steps in research, pp. 69-97, Van Schaik Publishers, Pretoria.

Ortlipp, M., 2008, 'Keeping and using reflective journals in the qualitative research process', The Qualitative Report 13(4), 695-705.

Patton, M. Q., 2002, 'Qualitative research and evaluation methods', 3rd edn., Sage Publications, Thousand Oaks, CA.

Prelip M., Slusser W., Thai C.L., Kinsler J., Erausquin J.T., 2011, 'Effects of a school-based nutrition program diffused throughout a large urban community on attitudes, beliefs, and behaviors related to fruit and vegetable consumption', Journal of School Health 81, 520-529. http://dx.doi.org/10.1111/j.1746-1561.2011.00622.x, PMid:21831064

Schönfeldt, H.C., Gibson, N. \& Vermeulen, H., 2010, 'The possible impact of inflation on nutritionally vulnerable households in a developing country using South Africa as a case study', Nutrition Bulletin 35, 254-267. http://dx.doi.org/10.1111/j.14673010.2010.01837.x

Silverman, A., 2010, 'Doing qualitative research', 3rd edn., SAGE Publications, London.

Spiegel, S.A. \& Foulk, D., 2006, 'Reducing overweight through a multidisciplinary schoolbased intervention', Obesity 14, 88-96. http://dx.doi.org/10.1038/oby.2006.11, PMid:16493126

Statistics South Africa (STATSSA), 2010, 'Millennium Development Goals, Country Report 2010', viewed 16 October 2013, from http://www.statssa.gov.za/news archive/ Docs/MDGR_2010.pdf

Steyn, N.P., Lambert, E.V., Parker, W., Mchiza, Z. \& De Villiers, A., 2009, 'A review of school nutrition interventions globally as an evidence base for the development of the HealthKick programme in the Western Cape, South Africa' South African Journal of Clinical Nutrition 22(3), 145-152.

Stuckler, D., Basu, S. \& McKee, M., 2010, 'Drivers of Inequality in Millennium Development Goal Progress: A Statistical Analysis', PLOS Medicine 7(3), e1000241 http://dx.doi.org/10.1371/journal.pmed.1000241

Taylor, P.C. \& Medina, M.N.D., 2013, 'Educational research paradigms: From positivism to multiparadigmatic', 'The Journal of Meaning-Centered Education 1(2), http:// www.meaningcentered.org/journal/volume-01/educational-research-paradigmsfrom-positivism-to-multiparadigmatic

Tessier, S., 2012, 'From field notes, to transcripts, to tape recordings: Evolution or combination?', International Journal of Qualitative Methods 11(4), 446-460.

Tomal, D.R., 2010, 'Action research for educators', 2nd edn., Rowman Littlefield, Maryland.

Tracy, S.J., 2010, 'Qualitative quality: Eight "Big-Tent" criteria for excellent qualitative research', Qualitative Inquiry 16, 837-851. http://dx.doi.org/10.1177/1077800 410383121

Tudge, J.R.H., Mokrova, I., Hatfield B.E. \& Karnik, R.B., 2009, 'Uses and misuses of Bronfenbrenner's Bioecological Theory of human development', Journal of Family Theory and Review 1, 198-210. http://dx.doi.org/10.1111/j.1756-2589.2009.00026.x

United Nations (UN), 2012, 'The Millennium Development Goals Report 2012', viewed 16 October 2013, from http://www.undp.org/content/dam/undp/library/MDG/ english/The_MDG_Report 2012.pdf 